\title{
Effect of hypophysectomy on the gastric mucosa of the rat
}

\author{
GERARD P. CREAN ${ }^{1}$ \\ From the Medical Research Council Clinical Endocrinology Research Unit, \\ University of Edinburgh
}

Although it is generally accepted that the endocrine system may influence the secretory function of the stomach, relatively little attention has been paid to the further possibility that the endocrines may also regulate the actual growth of the gastric mucosa; however, there is a considerable body of evidence (Crean, 1963a) to support this idea which was first envisaged by Spence and Witts in 1939. For example, severe gastric atrophy is known to occur in patients with pituitary or adrenocortical insufficiency (Feyrter and Klima, 1952; Smith, Delamore, and Wynn Williams, 1961) while it has been shown that hypophysectomy causes a marked reduction in the weight of the gastric and intestinal mucosa in experimental animals (Schooley, Riddle, and Bates, 1941; Haeger, Jacobsohn, and Kahlson, 1953); it has been reported also that the parietal cell population was reduced by about $50 \%$ after hypophysectomy in rats although no data were given to indicate how this conclusion was reached (Friedman, 1953). Moreover, the parietal and peptic cells appear to depend on the endocrine system for their structural integrity since both cell types show involutional changes after hypophysectomy or adrenalectomy (Baker, 1955, 1957, 1958; Baker and Abrams, 1954; Abrams and Baker, 1954; Baker and Clarke, 1961; Baker and Pliske, 1957).

This paper reports the results of three experiments in rats in which the effects of hypophysectomy on the growth of the gastric mucosa were determined from the changes observed in the weight of the stomach, the surface area, height and volume of the fundic mucosa, and the total parietal cell population of the stomach; a preliminary account of some of the results obtained has been given elsewhere (Crean, 1961; 1963b).

ESTIMATION OF THE PARIETAL CELL POPULATION AND VOLUME OF THE GASTRIC MUCOSA

The total parietal cell population of the stomach and

'Present address: Gastrointestinal Centre, Southern General Hospital, Glasgow, S.W.1. the surface area and volume of the gastric mucosa were estimated according to the methods described originally by Cox and Barnes (1945) as modified by Card and Marks (1960); substantially the same methods have been used to estimate the parietal cell population of the whole or resected human stomach (Cox, 1952; Card and Marks, 1960) and of the whole stomach of the dog, guinea-pig, and rat (Marks, Komarov, and Shay, 1960; Reid, Hackett, and Welbourn, 1961; Cox and Barnes, 1945; Marks, 1957; Bralow and Komarov, 1962; Bralow, Komarov, and Shay, 1964).

PREPARATION OF STOMACH AND MEASUREMENT OF AREA In the present experiments the rat was killed by exposure to chloroform. The stomach was opened along the greater curvature, and pinned serosal surface downwards on a sheet of unexposed $x$-ray film which was fixed on a base of beeswax in a shallow trough, the organ being pinned on the $x$-ray film in such a way as to eliminate all mucosal folds. In the rat, the fundus and the antrum of the stomach are readily distinguished from one another on naked-eye examination; pins were placed at intervals along the junction lines between the antrum and fundus, so that the boundary between the two parts was permanently outlined on the $x$-ray film by a series of pin holes. The preparation was then fixed by immersion in $10 \%$ formol-saline for $\mathbf{3 8}$ hours and after fixation the stomach was dried by swabbing and weighed.

As pointed out by Card and Marks (1960), unexposed $x$-ray film was useful in providing an exact outline of the surface area of the stomach because the exposed part darkens in colour whereas the area cocupied by the stomach remains light green. The area occupied by the fundus on the $x$-ray film was determined from the average of three consecutive readings with a planimeter; the coefficient of variation of the consecutive observations on 50 stomachs was $1.5 \%$.

SAMPLING PROCEDURE AND HISTOLOGICAL OBSERVATIONS Six full-thickness strips of the stomach wall were excised from the area of the fundic mucosa, as illustrated in Figure 1. Longitudinal sections were cut from each strip at right angles to the surface of the mucosa using a nominal microtome setting of $5 \mu$; the sections were stained by the method of Marks and Drysdale (1957).

Parietal cell counts were carried out under oil (magnification, approximately $\times 900$ ) using a calibrated squared 


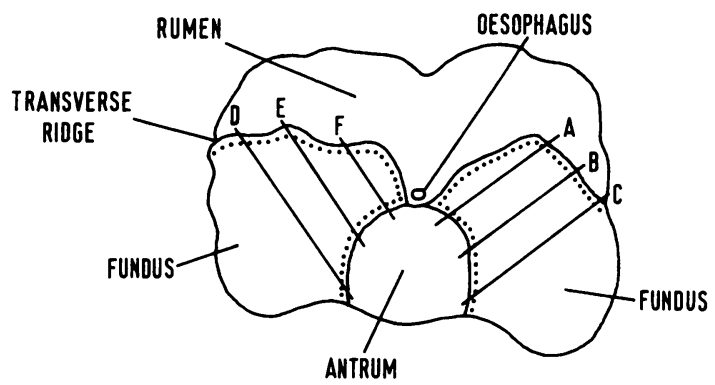

TRAMSITIONAL AREAS

FIG. 1. Diagrammatic representation of the method of selecting the sample strips from the gastric mucosa.

grid graticule in the eyepiece. A single 'count' represented all parietal cell nuclei or nuclear fragments seen in a column of tissue $0.1 \mathrm{~mm}$ broad extending from the base to the surface of the mucosa. Counts were repeated at intervals of $2 \mathrm{~mm}$ along the length of each slide, and an 'average count per unit area' was calculated for each stomach by dividing the number of cells seen by the number of counts made; peptic cells may be counted in the same way (Crean, 1967). The height of the mucosa was measured at intervals of $4 \mathrm{~mm}$ along the length of each section (magnification, approximately $\times 90$ ) using the calibrated eyepiece, and an average mucosal height was calculated for each stomach. These histological observations were confined to true fundic mucosa, the transitional type mucosa which separates the fundus from the antrum and the cardiac type mucosa adjacent to the transverse ridge (Baker and Bridgeman, 1954) being excluded from consideration.

CORRECTION FACTORS Two correction factors were applied to the histological observations.

'Shrinkage factor' This was applied to compensate for the tissue shrinkage which occurs during histological processing. Longitudinal shrinkage (LSF) was determined by dividing the length of each tissue strip after staining by its length when it was taken from the stomach; the total shrinkage factor for each strip was taken to be $(\mathrm{LSF})^{2}$ on the assumption that shrinkage would occur equally in both horizontal and longitudinal planes (Card and Marks, 1960). Shrinkage was calculated in this way for 147 sections representing 29 stomachs from four experimental groups. Analysis of variance of these data (Table I) showed that there was no significant difference in the observed value for shrinkage between the four treatment groups; the mean of these observations has been taken to represent a reasonable estimate of total shrinkage and this value $(0.833)$ has been applied to all the data presented in this paper.

Overestimation of the nuclear population The crude cell count in a given microtome section overestimates the true density of the cells in the tissues since the section under consideration necessarily includes fragments of
TABLE I

VARIATION IN 'SHRINKAGE FACTOR' BETWEEN 29 STOMACHS REPRESENTING FOUR TREATMBNT GROUPS

Variation Analysis of Variance

\begin{tabular}{ccccc}
\hline $\begin{array}{l}\text { Degrees } \\
\text { of } \\
\text { Freedom }\end{array}$ & $\begin{array}{l}\text { Sum of } \\
\text { Squares }\end{array}$ & $\begin{array}{l}\text { Mean } \\
\text { Square }\end{array}$ & $\begin{array}{l}\text { Variance } \\
\text { Ratio }\end{array}$ & $\begin{array}{l}\text { Value for } \\
P\end{array}$ \\
\hline 3 & 0.004 & 0.0013 & 1.4 & N.S. \\
25 & 0.0248 & 0.00099 & & \\
28 & 0.0288 & & & \\
\hline
\end{tabular}

cells belonging to adjacent sections. Provided that the thickness of the section and the cross-sectional diameter of the cells are known, the crude count may be related to the true cell density according to a formula devised by Abercrombie (1946, formula 1). Both these measurements were made by direct micrometry on cross-sections prepared according to the method of Marengo (1944) from random samples of the actual sections used for the histological observations. At least 50 observations on section thickness and 100 observations on nuclear diameter were made at random on cross-sections obtained from each batch of sections prepared, and the mean value for each observation was applied in calculating the parietal cell population of the stomachs processed in the same batch; cross-sections were prepared separately for each experimental group to allow for the possibility that nuclear size might be affected by treatment.

CALCULATIONS The 'average count per unit area' represented the number of parietal cells contained within a column of tissue underlying a unit of the surface area of the mucosa. Given the dimensions of the unit area considered, namely the thickness of the section and the width $(0.1 \mathrm{~mm})$ of the column of tissue examined, the 'count per unit area' could be referred to the surface area of the fundus to provide an estimate of the parietal cell population of the whole stomach. The volume of the gastric mucosa was calculated as the product of the mean mucosal height and surface area; since the density of a cell is about unity, the measurement of the volume of the mucosa approximates that of its mass.

ERRORS There were at least three major sources of error which might influence the results obtained in the investigation.

Subjective bias on the part of the observer The subjective process of cell counting might be influenced by prejudgement concerning the results to be expected in any particular experiment. This source of error was eliminated by having all the sections re-labelled by a third party according to a set of random numbers so that to the observer each section to be examined was an 'unknown'.

Observer errors Errors could also arise due to inconsistencies in identifying or counting parietal cells or to lack of precision in microscopic measurements. The magnitude of these errors was estimated by testing the reproducibility of the results obtained (a) when replicate observations were made at different times on the same sections, and $(b)$ when duplicate sections were 
examined at different times. In all instances the second set of observations was made under 'unknown' conditions; as tested in this way parietal cell counts (and also peptic cell counts) and the measurements of mucosal height, nuclear diameter, and section thickness were reproducible within the limits of error of the order of $5 \%$.

Sampling errors The arbitrary selection of sample strips from the gastric mucosa might give rise to errors due to variation either in the distribution of parietal cells or in the height of the gastric mucosa between different parts of the stomach; if so, the sample strips might not be truly representative of the entire fundic mucosa. This source of error was tested by examining the actual variation observed in the 'average count per unit area' and the height of the gastric mucosa in the data taken from three experimental treatment groups, representing 23 stomachs or 138 individual strips, by the method of analysis of variance. The results (Table II and III) show that there was no significant variation in the values obtained for either observation as between the six sites sampled in individual stomachs; moreover, the results computed on two strips only (strips B and E, Fig. 1) proved to be indistinguishable from those computed on all six strips, when the same data were tested according to Scheffe's method of multiple contrasts (Scheffe, 1959).

\section{TABLE II}

VARIATION IN AVERAGE 'COUNT' PER UNIT AREA BETWEEN SIX SAMPLE STRIPS FROM 23 STOMACHS REPRESENTING THREE TREATMENT GROUPS

Variation Analysis of Variance

\begin{tabular}{lccccl} 
& $\begin{array}{l}\text { Degree of } \\
\text { Freedom }\end{array}$ & $\begin{array}{l}\text { Sum of } \\
\text { Squares }\end{array}$ & $\begin{array}{l}\text { Mean } \\
\text { Square }\end{array}$ & $\begin{array}{c}\text { Variance } \\
\text { Ratio }\end{array}$ & $\begin{array}{l}\text { Value for } \\
P\end{array}$ \\
\hline Strips & 5 & 87.38 & 17.48 & 1.85 & $\begin{array}{l}\text { Not } \\
\text { significant } \\
\text { ind }\end{array}$ \\
Stomachs & 22 & 3274.54 & 148.8 & 15.7 & $<001$ \\
Error & 110 & 1041.41 & 9.47 & & \\
Total & 137 & & & &
\end{tabular}

\section{TABLE III}

VARIATION IN MEAN HEIGHT OF FUNDIC MUCOSA BETWEEN SIX SAMPLE STRIPS FROM 23 STOMACHS REPRESENTING THREE TREATMENT GROUPS

(SAME ANIMALS AS IN TABLE II)

Variation Analysis of Variance

\begin{tabular}{|c|c|c|c|c|c|}
\hline & $\begin{array}{l}\text { Degrees of } \\
\text { Freedom }\end{array}$ & $\begin{array}{l}\text { Sum of } \\
\text { Squares }\end{array}$ & $\begin{array}{l}\text { Mean } \\
\text { Square }\end{array}$ & $\begin{array}{l}\text { Variance } \\
\text { Ratio }\end{array}$ & $\begin{array}{l}\text { Value for } \\
P\end{array}$ \\
\hline Strips & 5 & 1.87 & 0.374 & $1 \cdot 15$ & $\begin{array}{l}\text { Not } \\
\text { significant }\end{array}$ \\
\hline $\begin{array}{l}\text { Stomachs } \\
\text { Error }\end{array}$ & $\begin{array}{r}22 \\
110\end{array}$ & $\begin{array}{r}137.69 \\
35.65\end{array}$ & $\begin{array}{l}6 \cdot 26 \\
0 \cdot 324\end{array}$ & $19 \cdot 3$ & $<0.001$ \\
\hline
\end{tabular}

Total 137

The results of this analysis suggested that reliable results could be obtained with less effort by examining fewer strips; accordingly, the sampling procedure was modified and for the majority of the experiments carried out in the laboratory (including experiments II and III in the present communication), the data have been calculated from observations made on the sample strips $\mathrm{B}$ and $\mathrm{E}$ only.

\section{EXPERIMENTAL PROCEDURES AND MATERIALS}

Only male rats were used, those in experiment $\mathrm{I}$ being obtained from the closed Wistar colony bred in the Clinical Endocrinology Research Unit, and those in experiments II and III from the Sprague-Dawley strain maintained in the Charles River Breeding Laboratories Inc., Boston, Mass., U.S.A.

Hypophysectomy was performed by the parapharyngeal route. By sham hypophysectomy is meant an operation which is identical to that performed when the pituitary is to be removed up to and including the making of a burr hole in the base of the skull; in the sham procedure the pituitary is left in situ, whereas it is removed by suction when an actual hypophysectomy is to be performed. The operations required for experiments II and III were performed on the same day in Boston; the animals were shipped immediately by air to Edinburgh, and the two experiments were considered to begin when they arrived in the laboratory on the first day after operation. The completeness of hypophysectomy was confirmed in all cases (except in the three animals specified in experiment III) by failure of the animals to gain weight, by careful examination of the pituitary fossa with a hand lens at necropsy, and by regression in the weight of the paired adrenals and testes; the weights of these organs are given in the tables for each experiment.

In experiments II and III, sham-hypophysectomized animals were deliberately underfed in order to reduce their mean body weight to the same level as that of the hypophysectomized animals with which they were being compared. Underfeeding was practised on a purely empirical basis, and the amount of food given to the underfed animals varied from day to day according to their mean body weight and that of the hypophysectomized group. With practice, the amount of food required to be given to each animal for this purpose was judged fairly accurately, and the growth curves of the individual underfed animals were remarkably smooth. The diet used in experiments II and III was composed of the special rat cake used in this Unit and brown bread pulped to softness with fresh milk and glucose. This was provided in bulk twice daily for the hypophysectomized animals and the groups fed ad libitum, whereas the underfed animals were fed individually, once daily; in experiment I, the controls and the hypophysectomized animals were given the same diet of standard rat cake. The same drinking fluid of $5 \%$ glucose and $1 \%$ saline in tap water with added vitamin supplements was provided ad libitum to all animals except the 'controls' in experiment I which received tap water.

The adrenals and testes were removed from all animals at necropsy and placed in $10 \%$ formol-saline; the organs from all the animals in the same experiment were weighed subsequently on the same day after being dried by swabbing. As an additional assessment of somatic growth the width of the tibial epiphyseal cartilage was measured in experiment II according to the method of Greenspan, Li, Simpson, and Evans (1950) using one tibia from each animal. 
EXPERIMENT I This was a pilot experiment in which the stomachs of young hypophysectomized rats killed three weeks after operation were compared with the stomachs of intact animals of similar body weight.

Experimental method Hypophysectomy was performed on rats aged about six weeks and weighing between 100 and $120 \mathrm{~g}$. Eleven animals judged to be completely hypophysectomized were selected for the experiment; each experimental animal was weighed on the 21st day after operation and an intact rat of similar weight was selected from the colony as a 'control', both animals being killed on the same day.

One of the control animals has been excluded from consideration in the results because damage to the stomach precluded useful histological observations being made. The results are summarized in Table IV and they may be considered according to the following headings.

Intact and hypophysectomized animals compared by weight and age There was no significant difference in mean body weight between the two groups on the day the animals were killed. However, the control rats were on average three weeks younger than the hypophysectomized group; the age difference between the two groups arises from the fact that somatic growth ceases after the pituitary has been removed in this species, so that the body weight of a young rat remains relatively unchanged from the day of hypophysectomy for the duration of its life (see Fig. 2).

Two groups compared with respect to the stomach There were large differences between the stomachs of the two groups; thus the mean values for stomach weight, surface area, mucosal height, mucosal volume, and total parietal cell population were all significantly less in the hypophysectomized animals than they were in the controls, the value for $P$ for the differences between the means varying from $<0.05$ to $<0.001$ for individual observations (Table IV).

Comment Since animals of the same body weight are known to have stomachs of roughly the same proportions (Brodie, 1945; Donaldson, 1930; Crean, 1967) it was concluded from these results that hypophysectomy had exerted a marked effect on the gastric mucosa. This conclusion is strengthened when the difference in the age of the two groups is taken into account, because normal rats of the same age as that of the hypophysectomized animals would have even larger stomachs than the control rats actually used. Moreover, since the values observed for the various gastric parameters in the control group must represent the extent to which the gastric mucosa had developed in these animals at the time they were killed, it may be implied that hypophysectomy had in some way retarded the growth of the gastric mucosa. However, the conditions of the experiment allowed two hypotheses to account for the results observed. These were: (1) That the retardation in the growth of the gastric mucosa after hypophysectomy was a direct result of pituitary deprivation per se. (2) That the retardation in the growth of the gastric mucosa was imposed by the limitation in the growth of the whole organism after hypophysectomy, and so only an indirect effect of pituitary deprivation.

In order to distinguish between these two hypotheses the following experiment was carried out.

EXPERIMENT II Hypophysectomized rats were compared with two groups of sham-hypophysectomized 'controls', one of which was allowed to feed ad libitum and develop normally during the course of the experiment, while the other was deliberately under-

TABLE IV

RESULTS OBTAINED IN EXPERIMENT I

\begin{tabular}{|c|c|c|c|c|c|c|c|c|}
\hline $\begin{array}{l}\text { Approxi- } \\
\text { mate Age } \\
\text { (days) }\end{array}$ & $\begin{array}{l}\text { Body } \\
\text { Weight (g) }\end{array}$ & $\begin{array}{l}\text { Weight of } \\
\text { Whole } \\
\text { Stomach (mg) }\end{array}$ & $\begin{array}{l}\text { Surface } \\
\text { Area of } \\
\text { Fundus } \\
(\text { sq cm })\end{array}$ & $\begin{array}{l}\text { Mean } \\
\text { Height of } \\
\text { Fundic } \\
\text { Mucosa }(\mathrm{mm})\end{array}$ & $\begin{array}{l}\text { Volume of } \\
\text { Fundic } \\
\text { Mucosa (c mm })\end{array}$ & $\begin{array}{l}\text { Total } \\
\text { Parietal } \\
\text { m) Cell } \\
\text { Population } \\
\text { (millions) }\end{array}$ & $\begin{array}{l}\text { Weight of } \\
\text { Paired } \\
\text { Adrenals } \\
(\boldsymbol{m g})\end{array}$ & $\begin{array}{l}\text { Weight of } \\
\text { Paired } \\
\text { Testes (g) }\end{array}$ \\
\hline
\end{tabular}

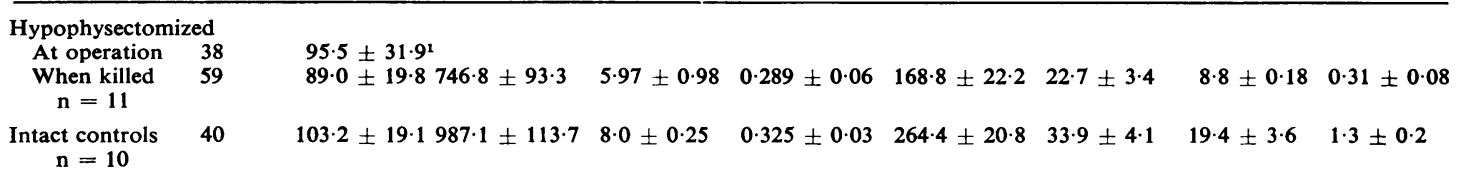

Comparison between the

$\begin{array}{lllllllll}\text { means } & t=1.67 & t=5.2 & t=5.2 & t=2.1 & t=8.2 & t=6.7 & t=8.6 & t=14.1\end{array}$

Degrees of freedom $=19 \quad P<0.2 \quad P<0.001 \quad P<0.001 \quad P<0.05 \quad P<0.001 \quad P<0.001 \quad P<0.001 \quad P<0.001$

${ }^{1}$ The difference in mean body weight of the hypophysectomized group between the time of operation and the time they were killed was not significant $(P<0.2)$ 


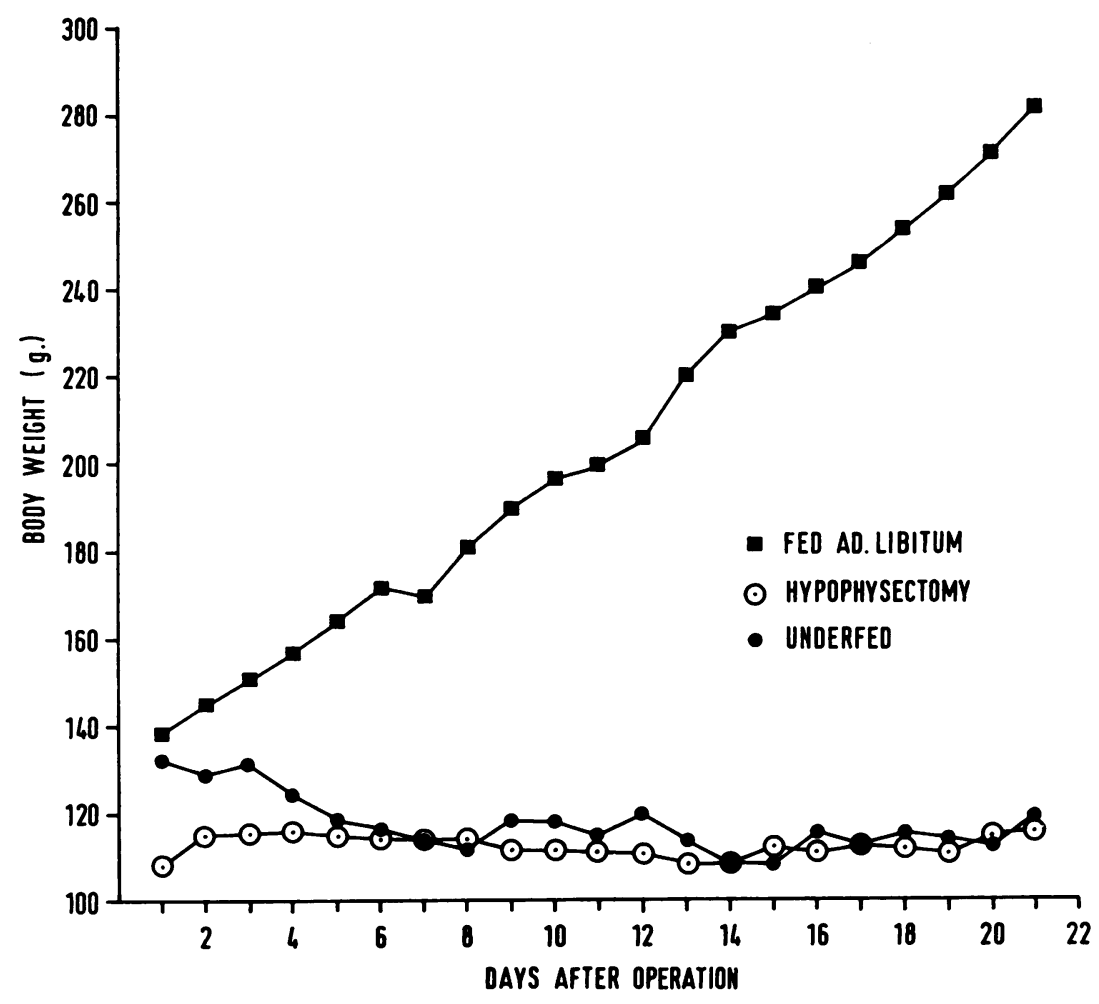

FIG. 2. The mean body weight curves of the sham-hypophysectomized animals fed ad libitum (group I), the sham-hypophysectomized underfed animals (group II), the hypophysectomized animals (group III).

fed so as to restrict their mean body weight to the same extent as that of the hypophysectomized animals.

Experimental method Eighteen young male rats were selected within the weight range of $120 \pm 10 \mathrm{~g}$ from a homogeneous population and sham-hypophysectomized or hypophysectomized on the same day in the proportion of 2:1 according to a predetermined random order. The experiment was considered to begin on the first day after operation, when the sham-hypophysectomized animals were randomly allocated to treatment by feeding ad libitum or by underfeeding. The experiment was thus composed of three treatment groups, namely, sham-hypophysectomized, fed ad libitum (group I), sham-hypophysectomized, underfed (group II), and hypophysectomized, fed ad libitum (group III). The three groups were caged separately, six to a cage, in the same room for the duration of the experiment. One of the hypophysectomized animals died after 10 days, and has been excluded from consideration in the results; the remaining animals were killed on the 23 rd day after operation.

The results of the experiment are summarized in Table $\mathrm{V}$ and illustrated in Figs. 2 and 3 and they may be considered according to the following headings.
Three groups compared with respect to somatic growth The mean initial body weight of the hypophysectomized animals, ie, body weight on the first postoperative day, was significantly less (P $<0.001)$ than that of either of the sham-hypophysectomized groups, despite the fact that the original sample population had been selected within a narrow weight range of $120 \pm 10 \mathrm{~g}$ at the time of operation in Boston on the previous day. This effect is attributed to differences in food intake between the hypophysectomized and sham-hypophysectomized animals while in transit to Edinburgh, and to the more severe disturbance in general health caused by hypophysectomy. However, as a result of food restriction the mean body weight of the underfed group was reduced to that of the hypophysectomized animals by the fourth day of the experiment, and the subsequent growth curves and mean final body weights of the two groups were indistinguishable from one another (see Table $\mathrm{V}$ and Fig. 2). The sham-hypophysectomized animals allowed to feed ad libitum grew at a normal rate during the course of the experiment, indicating that the operation of sham-hypophysectomy had not exerted any appreciable effect on somatic growth. The data for tibial epiphyseal cartilage width 
VOLUME OF FUNDIC MUCOSA

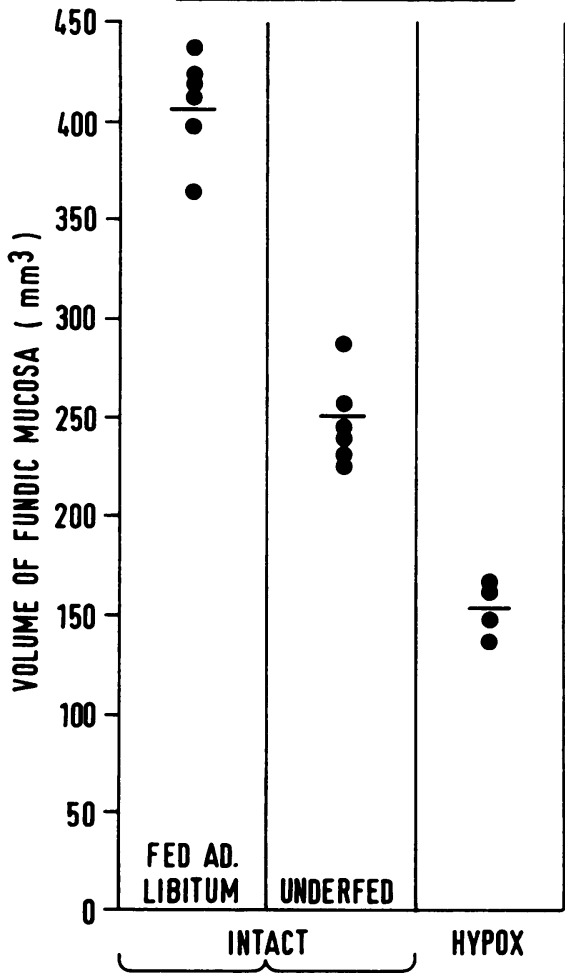

TOTAL PARIETAL CELL POPULATION

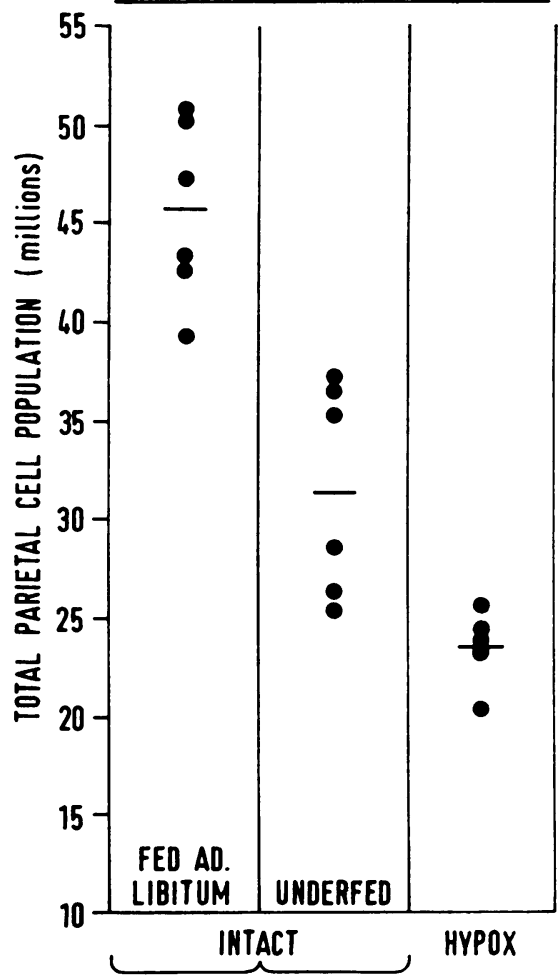

FIG. 3. Scattergram of the data obtained for mucosal volume and total parietal cell population in individual animals in experiment II.

TABLE V

RESULTS OBTAINED IN EXPERIMENT II

\begin{tabular}{|c|c|c|c|c|c|c|c|c|c|}
\hline $\begin{array}{l}\text { Initial } \\
\text { Body } \\
\text { Weight } \\
(\mathrm{g})\end{array}$ & $\begin{array}{l}\text { Final } \\
\text { Body } \\
\text { Weight } \\
(\mathrm{g})\end{array}$ & $\begin{array}{l}\text { Width of } \\
\text { Tibial } \\
\text { Epi- } \\
\text { physeal } \\
\text { Cartilage } \\
(\mu)\end{array}$ & $\begin{array}{l}\text { Weight of } \\
\text { Whole } \\
\text { Stomach } \\
\text { (mg) }\end{array}$ & $\begin{array}{l}\text { Surface } \\
\text { Area of } \\
\text { Fundus } \\
(s q \mathrm{~cm})\end{array}$ & $\begin{array}{l}\text { Height of } \\
\text { Fundic } \\
\text { Mucosa } \\
(\mathrm{mm})\end{array}$ & $\begin{array}{l}\text { Volume } \\
\text { of Fundic } \\
\text { Mucosa } \\
\text { (c mm) }\end{array}$ & $\begin{array}{l}\text { Total } \\
\text { Parietal } \\
\text { Cell } \\
\text { Popula- } \\
\text { tion } \\
\text { (millions) }\end{array}$ & $\begin{array}{l}\text { Weight } \\
\text { of Paired } \\
\text { Adrenals } \\
(m g)\end{array}$ & $\begin{array}{l}\text { Weight } \\
\text { of Paired } \\
\text { Testes } \\
(\mathrm{g})\end{array}$ \\
\hline
\end{tabular}

Group I

sham-hypophysectomized, fed ad libitum

$\mathrm{n}=6$

\begin{tabular}{|c|c|c|c|c|c|c|c|c|c|}
\hline $\begin{array}{l}138.8 \\
\pm \quad \\
3.7\end{array}$ & $\begin{array}{l}282 \cdot 1 \\
\pm \\
16 \cdot 4\end{array}$ & $\begin{array}{l}276 \cdot 3 \\
\pm \\
11 \cdot 6\end{array}$ & $\begin{array}{l}1552.7 \\
\pm \quad \\
\quad 37.4\end{array}$ & $\begin{array}{l}11.34 \\
\pm \\
0.9\end{array}$ & $\begin{array}{l}0.367 \\
\pm \\
0.031\end{array}$ & $\begin{array}{l}409 \cdot 3 \\
\pm \\
25 \cdot 7\end{array}$ & $\begin{array}{l}46.0 \\
\pm \\
4.9\end{array}$ & $\begin{array}{l}45.9 \\
\pm \\
6.8\end{array}$ & $\begin{array}{l}3 \cdot 15 \\
\pm \\
0 \cdot 188\end{array}$ \\
\hline $\begin{array}{l}132.5 \\
\pm \quad 3.4\end{array}$ & $\begin{array}{l}116.0 \\
\pm \\
6.02\end{array}$ & $\begin{array}{l}149 \cdot 2 \\
\pm \\
10 \cdot 2\end{array}$ & $\begin{array}{l}878.8 \\
\pm \\
106.5\end{array}$ & $\begin{array}{l}8.03 \\
\pm \\
1.09\end{array}$ & $\begin{array}{l}0.314 \\
\pm \\
0.032\end{array}$ & $\begin{array}{l}249 \cdot 8 \\
\pm \\
20 \cdot 3\end{array}$ & $\begin{array}{l}31.6 \\
\pm \\
5.5\end{array}$ & $\begin{array}{l}26 \cdot 7 \\
\pm \\
7 \cdot 2\end{array}$ & $\begin{array}{l}2 \cdot 42 \\
\pm \\
0 \cdot 160\end{array}$ \\
\hline $\begin{array}{l}108 \cdot 2 \\
\pm \quad 6 \cdot 2\end{array}$ & $\begin{array}{l}112 \cdot 6 \\
\pm \\
11 \cdot 3\end{array}$ & $\begin{array}{l}132 \cdot 0 \\
\pm \quad \\
5 \cdot 3\end{array}$ & $\begin{array}{l}702.4 \\
\pm \quad 88.4\end{array}$ & $\begin{array}{l}5.89 \\
\pm \\
0.47\end{array}$ & $\begin{array}{l}0.266 \\
\pm \\
0.030\end{array}$ & $\begin{array}{l}156 \cdot 2 \\
\pm \\
10 \cdot 7\end{array}$ & $\begin{array}{l}23 \cdot 7 \\
\pm \\
1.8\end{array}$ & $\begin{array}{l}10 \cdot 6 \\
\pm \\
4 \cdot 0\end{array}$ & $\begin{array}{l}0.355 \\
\pm \\
0.036\end{array}$ \\
\hline $\begin{array}{l}t=9.59 \\
P<.001\end{array}$ & $\begin{array}{l}t=22.3 \\
P<.001\end{array}$ & $\begin{array}{l}t=11.4 \\
P<.001\end{array}$ & $\begin{array}{l}t=20.0 \\
P<\cdot 001\end{array}$ & $\begin{array}{l}t=13 \cdot 2 \\
P<.001\end{array}$ & $\begin{array}{l}t=5.43 \\
P<.001\end{array}$ & $\begin{array}{l}t=22 \cdot 1 \\
P<\cdot 001\end{array}$ & $\begin{array}{l}t=9.4 \\
P<.001\end{array}$ & $\begin{array}{l}t=10.5 \\
P<0.601\end{array}$ & $\begin{array}{l}t=36.2 \\
P<0.001\end{array}$ \\
\hline $\begin{array}{l}t=5.5 \\
P<.001\end{array}$ & $\begin{array}{l}t=0.6 \\
P<.6\end{array}$ & $\begin{array}{l}t=0.7 \\
P<\cdot 5\end{array}$ & $\begin{array}{l}t=3.0 \\
P<.02\end{array}$ & $\begin{array}{l}t=4.32 \\
P<.005\end{array}$ & $\begin{array}{l}t=2.55 \\
P<0.05\end{array}$ & $\begin{array}{l}t=9.7 \\
P<.001\end{array}$ & $\begin{array}{l}t=3 \cdot 3 \\
P<\cdot 01\end{array}$ & $\begin{array}{l}t=4.97 \\
P<0.001\end{array}$ & $\begin{array}{l}t=30.6 \\
P<0.001\end{array}$ \\
\hline$=1 \cdot 7$ & $t=23 \cdot 2$ & $t=8 \cdot 1$ & $t=14.7$ & $t=5.8$ & $t=2.93$ & $t=11.9$ & $t=4.57$ & $t=4.95$ & $t=7.03$ \\
\hline
\end{tabular}

sham-hypophysectomized,

underfed

$\mathrm{n}=6$

Group III

hypophysectomized, fed

ad libitum

$\mathrm{n}=5$

Comparison group I vs group III ( 9 degrees of freedom)

Comparison group II vs group III (9 degrees of freedom)

$\mathrm{P}<.2 \quad \mathrm{P}<.001 \quad \mathrm{P}<.001 \quad \mathrm{P}<.001 \quad \mathrm{P}<.001 \quad \mathrm{P}<0.02 \quad \mathrm{P}<.001 \quad \mathrm{P}<.005 \quad \mathrm{P}<0.001 \quad \mathrm{P}<0.001$ 
confirm that somatic growth was inhibited to the same extent in the hypophysectomized and underfed animals, since the mean values obtained for this observation in the two groups $(132.0 \pm 5.3$ and $149 \cdot 2 \pm 01 \cdot 2 \mu$, respectively) were not significantly different from one another; by contrast, the cartilage width in the group allowed to feed ad libitum was very much greater $(276.3 \pm 11.6 \mu)$ and is of the order to be expected in normal animals of the same size (see Geschwind and $\mathrm{Li}, 1955$ ).

Three groups compared with respect to the gastric mucosa When the data for the hypophysectomized and underfed groups are compared with those obtained in the group fed ad libitum (see Table V and Fig. 3) it will be apparent that hypophysectomy and underfeeding both exerted marked effects on the gastric mucosa, the values for all parameters in these two groups being considerably less than those obtained in the animals fed ad libitum. However, hypophysectomy exerted a more marked effect than underfeeding, so that there were significant differences between the hypophysectomized and underfed animals with respect to stomach weight $(P<0.02)$, surface area $(P<0.005)$, mucosal height $(P<0.05)$, mucosal volume $(P<0.001)$, and total parietal cell population $(\mathrm{P}<0.01)$.

Comment Since somatic growth was inhibited to the same extent in the hypophysectomized and underfed groups, the difference between the two treatments on the gastric mucosa may be attributed with confidence to the presence or absence of the pituitary; the results imply that hypophysectomy exerts a specific effect on the growth of the gastric mucosa.

EXPERIMENT III This experiment was carried out in order to examine the effects of hypophysectomy on the gastric mucosa of adult rats.

Experimental method Fourteen adult male rats aged about 18 weeks were selected within a weight range of $300 \pm 10 \mathrm{~g}$ from a homogeneous population and hypophysectomized or sham-hypophysectomized at random on the same day. The experiment was considered to begin when the animals arrived in the laboratory on the first day after operation. The two groups were caged separately; the sham-hypophysectomized animals were deliberately underfed for the duration of the experiment so that they lost weight at the same rate as the hypophysectomized group. On the fourth day it became apparent that the pituitary had not been completely removed in three animals of the hypophysectomized group and these animals were caged separately for the remainder of the experiment. All the animals were killed on the 23rd day after operation; at necropsy it was confirmed that hypophysectomy was complete in four animals and incomplete in the three animals already mentioned.

The results obtained in the experiment are summarized in Table VI and they are illustrated in Figs. 4 and 5; the data given for the hypophysectomized group in the table refer only to the four animals in which the pituitary had been completely removed. The results may be considered according to the following headings.

Hypophysectomized and underfed animals compared with respect to somatic growth The mean initial body weight of the hypophysectomized animals was considerably less $(P<0.001)$ than that of the shamoperated controls, despite the fact that the original sample population had been selected within a narrow weight range at the time of operation in Boston on the previous day; this effect may be attributed to

TABLE VI

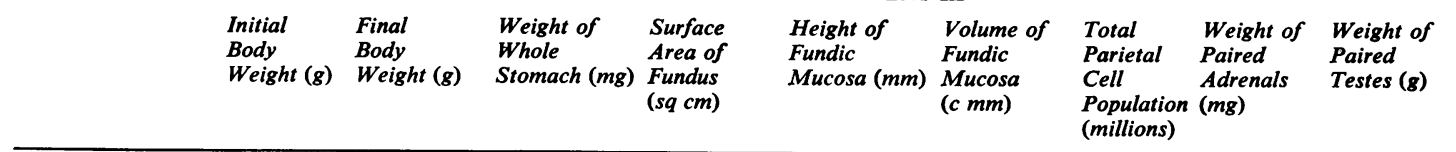

RESULTS OBTAINED IN EXPERIMENT II

Incompletely

hypophysectomized $289 \pm 9.9 \quad 344 \pm 59 \quad 1431 \pm 221 \quad 10.6 \pm 0.58 \quad 0.374 \pm 0.035 \quad 398.8 \pm 47 \quad 45.5 \pm 8.036 .7 \pm 12.13 .38 \pm 0.32$

$\mathbf{n}=\mathbf{3}$

Completely

hypophysectomized $257.5 \pm 3.4239 .5 \pm 12.81180 \pm 100 \quad 7.78 \pm 0.3 \quad 0.329 \pm 0.032 \quad 255.6 \pm 18 \quad 28.7 \pm 3.420 .1 \pm 4.6 \quad 1.47 \pm 0.174$

$\mathrm{n}=\mathbf{4}$

Underfed $\mathrm{n}=7 \quad 277 \cdot 4 \pm 2.8241 \cdot 4 \pm 8 \cdot 6 \quad 1413 \pm 143.9 \quad 10.68 \pm 0.96 \quad 0.332 \pm 0.037353 .2 \pm 35.938 .2 \pm 4.545 .5 \pm 5.0 \quad 3.58 \pm 0.222$

Comparison

between the means

obtained in the

completely hypo-

physectomized and

underfed animals

$(9$ degrees of

$t=9.94 \quad t=.265$

$\mathbf{P}<.001 \quad \mathrm{P}<.8$

$t=3 \cdot 152$

$\mathbf{t}=\mathbf{7 \cdot 2 5}$

$P<.001$

$t=0.14$
$P<.90$

$t=5.987$
$P<.001$

$\begin{array}{ll}t=4.0 & t=8.59 \\ P<.005 & P<.001\end{array}$

$t=17 \cdot 4$

freedom)

$t=3 \cdot 152$
$P<.02$

$P<.90$ 


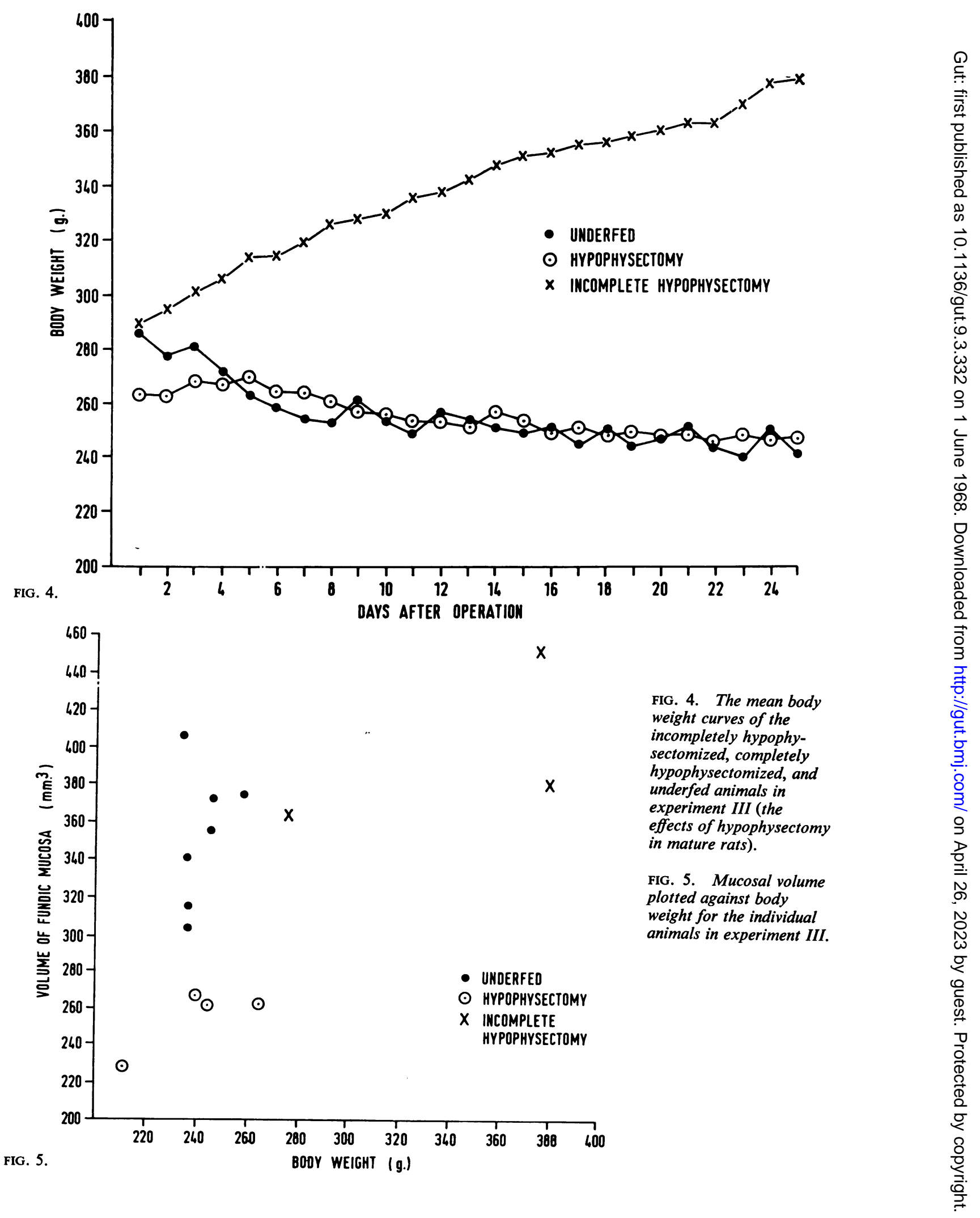


differences in food intake between the two groups while in transit to Edinburgh and to the more severe effects of hypophysectomy on the general health of the animals. As Fig. 4 shows, this difference in body weight was eliminated by the fourth day of the experiment as a result of the food restriction imposed on the underfed animals; the mean growth curves of the underfed and hypophysectomized groups were virtually identical for the remainder of the experiment, and there were no significant differences between the two groups with respect to final body weight. The incompletely hypophysectomized animals gained weight at a rate which might be expected of normal animals of the same age and starting weight, and it seems unlikely that the operation had exerted any marked effects on their somatic growth.

Two groups compared with respect to the gastric mucosa There were marked differences between the hypophysectomized animals and the sham operated controls with respect to all the observations made on the stomach except for mucosal height. The mean values for all the other parameters estimated were significantly less in the hypophysectomized group than they were in the underfed animals, the value for $P$ for the differences between the means being $<0.02$ for stomach weight and $<0.005$ for mucosal area, mucosal volume, and parietal cell population. The values obtained for all parameters in the incompletely hypophysectomized animals were considerably greater than those obtained in either of the other two groups, and were within the ranges to be expected for normal rats of similar age and body weight (Crean, 1967).

Comment Although only four completely hypophysectomized animals were available for consideration, the results clearly indicate that hypophysectomy per se exerts a marked effect on the growth of the gastric mucosa even in fully matured rats. When the data for individual animals are considered (see Fig. 5) it will be seen that the values obtained for mucosal volume were smaller in each of the hypophysectomized animals than they were in any individual animal in the underfed group; similarly there was no overlap in the values obtained for the parietal cell population between the two groups.

\section{DISCUSSION}

The methods of Cox and Barnes (1945) and Card and Marks (1960) have been used to estimate the volume (mass) of the fundic mucosa and the total parietal cell population in rats, and there is indirect evidence to suggest that the results obtained were reliable. The actual observations required for the calculations were reproducible within the limits of errors of $5 \%$, and analysis of the data from a large number of stomachs suggested that no serious errors arose from the method of sampling employed. Moreover, the values obtained for both estimates were reasonably constant from one experiment to another when differences in the age and body weight of individual animals were taken into account and the data for parietal cell population compare well with those of Bralow and Komarov (1962) and Bralow et al. (1964) for rats of comparable size. Furthermore, good correlations were found between the parietal cell population and mucosal volume $(r=0.87)$ (see Fig. 6) on the one hand, and between parietal cell population and stomach weight $(r=$ 0.86 ) on the other hand, and it is unlikely that correlations of this order would be obtained if either estimate were seriously in error. It should be emphasized that whatever the absolute errors involved in the methods used, they applied systematically throughout the investigation and since subjective errors were excluded the results may be regarded as sufficiently reliable to permit valid conclusions to be drawn from the experiments described.

Hypophysectomy was shown to reduce the weight of the stomach, the surface area and mucosal volume of the fundus, and the total parietal cell population in three experiments in rats; these results have been interpreted to mean that hypophysectoniy either retarded or caused a regression in the growth of the gastric mucosa as a whole. Moreover, under the conditions adopted in experiments II and III it was possible to show that the results observed were not due simply to the inhibition of somatic growth which follows hypophysectomy in the rat, but that they must represent a specific effect of pituitary deprivation on the stomach. The data obtained in the present investigation confirm previous suggestions (Spence and Witts, 1939; Haeger et al., 1953) that the pituitary is in some way responsible for maintaining the growth of the gastric mucosa not only in young growing animals but also in fully matured adult rats. Although the effect is a direct consequence of pituitary deprivation it remains to be established whether it is deficiency of the hormones of the pituitary itself, or deficiency of the hormones of one or other of the target endocrine organs that is the responsible mechanism.

A good correlation was obtained between mucosal volume and parietal cell population over the wide range of observations in all three experiments (see Fig. 6); this finding suggests that the main effect of hypophysectomy was to reduce the mass of the mucosa as a whole and that the parietal cell population had been reduced in simple proportion to the reduction in the amount of the secretory 


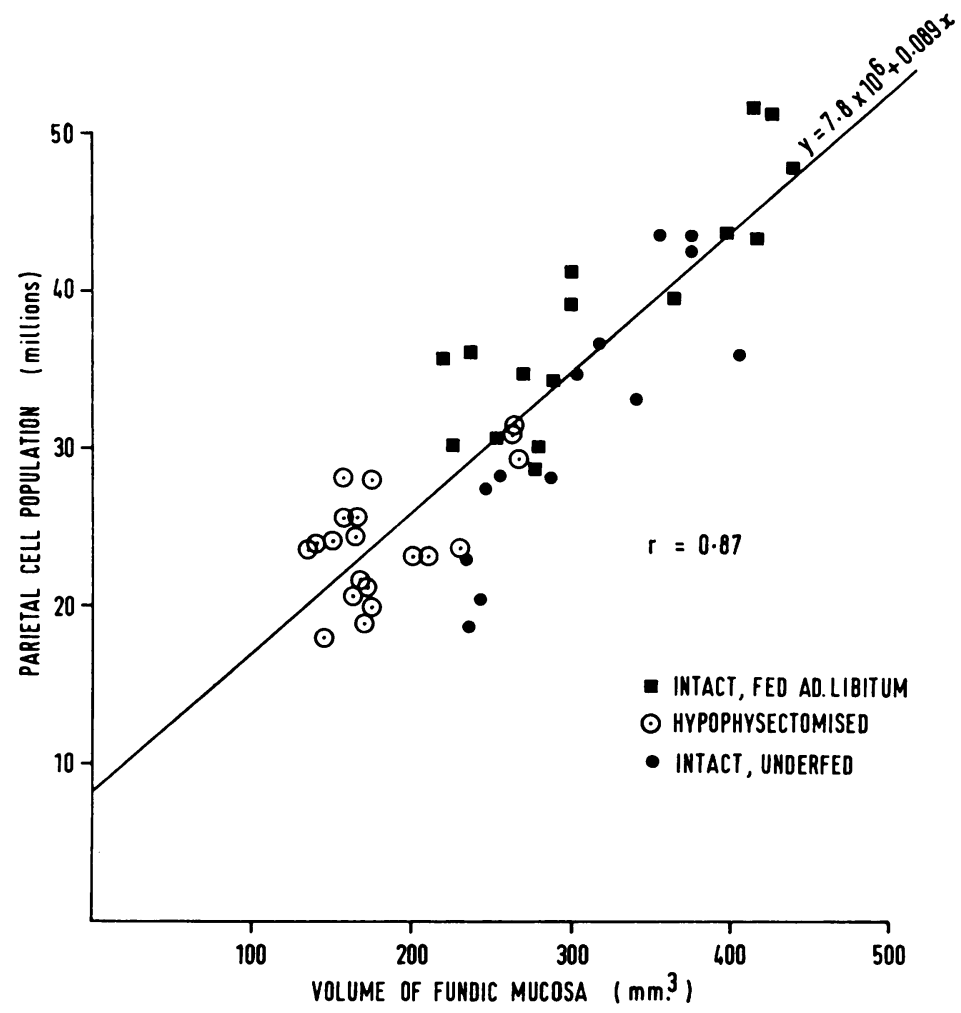

FIG. 6. The relationship between mucosal volume and total parietal cell population for all the animals in the three experiments.

tissue. The simplest explanation to account for the reduction in the mass of the mucosa would appear to be that hypophysectomy interferes in some way with the processes of cell division in the gastric mucosa either by reducing the rate of cell division or by reducing the total number of dividing cells or by exerting both effects. However, while hypophysectomy markedly reduces the mitotic activity of the mucous neck cells, it has the surprising effect of increasing the mitotic index of the superficial epithelial cells of the gastric mucosa (Belanger, 1960; Clark and Baker, 1963). These observations may be reconciled with the present results by supposing that there may be a form of maturation arrest in the processes of cell division within the gastric mucosa after hypophysectomy, so that the newly formed epithelial cells are not incorporated into the mass of the mucosa, but are lost at an excessive rate to the surface; on the other hand the reduction in the mitotic activity of the mucous neck cells would account for the decrease in the parietal cell population after hypophysectomy since it is believed that the secretory cells of the gastric mucosa are derived from the mucous neck cells by differentiation (Townsend, 1951; Hunt and Hunt, 1962). However, the mitotic index expresses only the numerical relationship between dividing and non-dividing cells in the tissues and does not allow for quantitative differences between the total number of cells in one organ as compared with another. Since there is a marked reduction in the mass of the gastric mucosa after hypophysectomy it is likely that the total number of dividing cells is also reduced despite the fact that the proportion of mitotic to non-mitotic cells is increased; clearly this possibility requires to be investigated before any final conclusions can be drawn concerning the mechanisms by which hypophysectomy interferes with the growth of the gastric mucosa. Not unexpectedly the results of the present experiments show that a marked inhibition of somatic growth produced by underfeeding exerts a considerable effect in retarding the growth of the gastric mucosa also.

\section{SUMMARY}

Methods described previously have been used to estimate the parietal cell population and the volume of the gastric mucosa in rats, and the major sources of error which might influence the results have been examined.

Hypophysectomy markedly reduced the weight of 
the whole stomach, the surface area and volume of the fundic mucosa, and the total parietal cell population both in young growing rats and in mature animals. It was shown that these effects must be due to a specific effect of pituitary deprivation on the stomach, and that they could not be accounted for simply by the inhibition of somatic growth which follows hypophysectomy in this species.

The results obtained confirm the suggestion that the pituitary gland exerts an important influence in regulating the growth of the gastric mucosa.

I wish to acknowledge my gratitude to Professor W. I. Card who suggested these investigations to $m e$ in the first place. I also wish to thank Dr J. A. Loraine, Dr K. E. Kirkham, and Dr Talib Astrabadi for their help and advice. The investigation would not have been possible but for the skilled technical assistance of Mr Alan Ross, Mr John Mitchell, Miss Alice Lawrie and Mr David Rumsey. The work was carried out during the tenure of a personal grant from the Medical Research Council.

\section{REFERENCES}

Abercrombie, M. (1946). Estimation of nuclear population from microtome sections. Anat. Rec., 94, 239-247.

Abrams, G. D., and Baker, B. L. (1954). The cytology and secretory activity of gastric zymogenic cells after ablation of ductless glands. Gastroenterology, 27, 462-468.

Baker, B. L. (1955). Adrenal steroids and the secretion of digestive enzymes. Ann. N.Y. Acad. Sci., 61, 324-327.

- (1957). The influence of the hypophysis and adrenals on digestive function. Amer. J. clin. Nutr., 5, 445-452.

- (1958). Restoration of involuted zymogenic cells in hypophysectomised rats by replacement therapy. Anat. Rec., 131, 389-403.

- , and Abrams, G. D. (1954). Effect of hypophysectomy on the cytology of the fundic glands of the stomach and on the secretion of pepsin. Amer. J. Physiol., 177, 409-412.

- - and Bridgeman, R. M. (1954). The histology of the gastrointestinal mucosa (rat) after adrenalectomy or administration of adrenocortical hormones. Amer. J. Anat., 94, 363-397.

- , and Clark, R. H. (1961). Influence of hypophysectomy on oxidative enzymes and size of parietal cells in gastric mucosa. Proc. Soc. exp. Biol. (N.Y.), 106, 65-67.

- , and Pliske, E. C. (1957). Endocrine regulation of zymogenic cells. Symp. Soc. exp. Biol., 11, 329-344.

Belanger, L. F. (1960). Increased mitotic activity in the glandular stomach of the rat following hypophysectomy. Endocrinology, 66, 886-888.

Bralow, S. P., and Komarov, S. A. (1962). Parietal cell mass and distribution in stomachs of Wistar rats. Amer. J. Physiol., 203, 550-552.

$\longrightarrow$, and Shay, H. (1964). Effect of total adrenalectomy on gastric secretion in chronic gastric fistula rats. Ibid., 206, $1309-1314$.

Brodie, S. (1945). In Bioenergetics and Growth, p. 628. Reinhold, New York.
Card, W. I., and Marks, I. N. (1960). The relationship between the acid output of the stomach following "maximal" histamine stimulation and the parietal cell mass. Clin. Sci., 19, 147-163.

Clark, R. H., and Baker, V. L. (1963). Effect of hypophysectomy on mitotic proliferation in gastric epithelium. Amer. J. Physiol. 204, 1018-1022.

Cox, A. J. (1952). Stomach size and its relation to chronic peptic ulcer. Arch. Path., 54, 407-422.

- and Barnes, V. R. (1945). Experimental hyperplasia of the stomach mucosa. Proc. Soc. exp. Biol. (N.Y.), 60, 118-120.

Crean, G. P. (1961). The effect of hypophysectomy on the gastric mucosa of the rat. J. Physiol. (Lond.), 159, 38-39P.

- (1963a). The endocrine system and the stomach. Vitam. and Horm., 21, 215-280.

- (1963b). The effect of hypophysectomy on the gastric mucosa of the rat. Proceedings, 2nd World Congress of Gastroenterology, vol. 2, edited by E. Schmidt, I. Tomenius, and G. Watkinson, pp. 87-91. Kager, Basel.

(1967). Observations on the regulation of the growth of the gastric mucosa. In Gastric Secretion, Mechanisms and Control. Proceedings of a symposium edited by T. K. Shnitka, J. A. L. Gilbert and R. C. Harrison, pp. 33-43. Pergamon, Oxford.

Donaldson, H. H. (1930). In The Rat (Memoirs of the Wistar Institute of Anatomy and Biology No. 6), p. 215. Philadelphia.

Feyrter, F., and Klima, R. (1952). Uber die magenveranderurgen bei der Addisonschen Krankheit. Dtsch. med. Wschr., 77, 1173-1175.

Friedman, M. H. F. (1953). The response of different regions of the gastrointestinal tract to normal and abnormal stimuli (Influence of feeding inert bulk material and of hypophysectomy). J. nat. Cancer Inst., 13, 1035-1038.

Geschwind, J. I., and $\mathrm{Li}$, C. H. (1955). In The Hypophyseal Growth Hormone, Nature and Actions, edited by $\mathbf{R}$. W. Smith, $\mathbf{O}$. $\mathbf{H}$. Gaebler and C. V. H. Long, p. 28. McGraw Hill, New York.

Greenspan, F. S., Li, C. H., Simpson, M. E., and Evans, H. M. (1950). In Hormone Assay, edited by C. W. Emmens, p. 273. Academic Press, New York.

Haeger, K., Jacobsohn, D., and Kahlson, G. (1953). Atrophy of the gastrointestinal mucosa following hypophysectomy or adrenalectomy. Acta physiol. scand., suppl. 111, 30, 161-169.

Hunt, T. E., and Hunt, E. A. (1962). Radioautographic study of proliferation in the stomach of the rat using thymidine- $\mathrm{H}^{3}$ and compound 48/80. Anat. Rec., 142, 505-517.

Marengo, N. P. (1944). Paraffin section thickness; direct method of measurement. Stain Technol., 19, 1-10.

Marks, I. N. (1957). The effect of prolonged histamine stimulation on the parietal cell population and the secretory function of the guinea-pig stomach. Quart. J. exp. Physiol., 42, 180-189.

—, and Drysdale, K. M. (1957). A modification of Zimmerman's method for differential staining of gastric mucosa. Stain Technol., 32, 48-50.

- - Komarov, S. A., and Shay, H. (1960). Maximal acid secretory response to histamine and its relation to parietal cell mass in the dog. Amer. J. Physiol., 199, 579-588.

Reid, N. C., Hackett, R. M., and Welbourn, R. B. (1961). The influence of cortisone on the parietal cell population of the stomach in the dog. Gut, 2, 119-112.

Scheffe, H. (1959). In The Analysis of Variance. Wiley, New York.

Schooley, J. P., Riddle, O., and Bates, R. W. (1941). Replacement therapy in hypophysectomised juvenile pigeons. Amer.J. Anat., 69, 123-157.

Smith, A. W., Delamore, I. W., and Wynn, Williams, A. (1961). Gastric acid secretion and mucosal appearances in Addison's disease and hypopituitarism. Gut, 2, 163-167.

Spence, A. W., and Witts, J. L. (1939). Substitution therapy in hypopituitarism. Quart. J. Med., 32, (n.s. 8), 69-77.

Townsend, S. F. (1961). Regeneration of gastric mucosa in rats. Amer. J. Anat., 109, 133-147. 